\title{
Menšinový jazyk jako obyvatelné místo. Vymístěný svět Imre Kertésze
}

\author{
Eleonóra Hamar
}

Jak se člověk stane bezdomovcem ve svém vlastním jazyce? Jaké mechanismy vymístění ho do takové situace dostanou? O jaké lidské zkušenosti metafora bezdomovectví-v-jazyce vlastně mluví? V jakém smyslu je, či může být, vůbec jazyk našim domovem? A když už je člověk z jazyka-domova vymístěn, jaké mu zbývají možnosti promluvy? Kde a jak takový jazykově vymístěný bezdomovec pobývá?

Následující text se pokouší o znovupromýšlení těchto, v hermeneutické filozofii, v jiné podobě a s jinými důrazy již artikulovaných otázek (srovnej např́klad Gadamer 2003). Pokouší se o jejich reformulaci a rozvinutí prostřednictvím interpretace menšinového jazyka jako jazyka určovaného svou situovaností v mocenském prostoru. Vycházejíc z vymezení menšinové literatury a menšinového jazyka Gillese Deleuze a Félixe Guattariho (2001, 2003), nebudu zde menšinový jazyk (čili onen jazyk ,bezdomovců“) pojímat ve smyslu jazyka etnické skupiny žijící ve společensky a politicky podřízené pozici, nýbrž ve smyslu ne-dominantního jazykového řádu v rámci určitého mocenského pole. Při promýšlení tohoto tématu mi budou hlavním východiskem (kromě již naznačeného konceptuálního rámce) texty Imre Kertésze, jejichž jazyk svou ilustrativní silou reprezentuje zkušenost bytí bezdomovcem ve vlastním jazyce, a umožňuje nám tak chápat jej jako jednu ze současných podob jazyka menšinového. Svou analýzu zakládám na několika Kertészových esejistických zamyšleních psaných od počátku devadesátých let převážně pro německé publikum a vydaných souhrnně mad’arsky pod názvem Vypovězený jazyk. Jde o eseje, jejichž širší intertextuální kontext vytváří Kertészův román Člověk bez osudu. Tento román lze interpretovat jako analytickou zprávu o procesu, v němž se bolestivě rodí Kertészova židovská identita a souběžně s ní se odehrává vymíst’ování/vymístění Kertésze do pozice cizince. Reflektujíc tuto provázanost Kertészových textů, budu sledovat, jak ve zmiňovaných esejích Kertész artikuluje paradoxní situaci toho, že člověk píše a myslí ve své mateřštině (v tomto př́padě v mad'arském jazyce) bez možnosti zakoušení oné samozřejmosti, jejíž existenci mezi člověkem a jeho důvěrně známou mateřštinou obvykle předpokládáme.

Mým záměrem je tematizovat zkušenost i koncept displacementu, jenž však v mém textu neznamená fyzické vysídlení, odsun, deportaci či donucení žít v exilu. Displacement zde spíše pojímám jako stav i důsledek hovoření, psaní a existence ve vymístěném diskurzu, jako hovoření, psaní a existenci v menšinovém jazyce. Zajímá mě tedy zkušenost člověka vymístěného do menšinového jazyka. A jelikož se jeho jazyk od jazyka dominantního většinového jazyka z hlediska kategoriálního rozlišování mezi národními jazyky neliší, pak tento člověk hovoří, píše a žije jako bezdomovec ve svém vlastním jazyce.

Před rozbor takto vymezené problematiky musím vsunout krátkou poznámku o intelektuálním kontextu, který ovlivňoval vznik mého textu. Během psaní jsem si častokrát kladla

Sociálni studia. Fakulta sociálních studií Masarykovy univerzity v Brně, 2/2004. S. 57-70. ISSN 1214-813X. 
otázku, jestli je ještě vůbec přínosné psát o Kertészových textech poté, kdy za svůj román Člověk bez osudu (v doslovném překladu Bezosudovost) získal v roce 2002 Nobelovu cenu za literaturu. Zda to tedy má smysl poté, co se jeho dílo dostalo - alespoň v určitých intelektuálních kruzích - do hlavního zorného pole, a o jeho textech již bylo napsáno množství analýz a úvah (viz např́klad György 2003, Nádas 2002, Vári 2002). Zda má ještě smysl opakovat či rozšiřovat to, co v té či oné podobě někde už určitě zaznělo. Pro ono ,přece jenom“, jež mě utvrdilo v dokončení rozepsaného, jsem našla dva jasné a závažné důvody (tedy kromě důvodu výchozího, jenž spočívá v interpretaci Kertészova jazyka ve smyslu jazyka menšinového). První důvod je metodologický a spočívá v tom, že prostřednictvím rozboru Kertészových textů v diskurzu sociologie můžeme nejenom hlouběji porozumět jeho textům jako konkrétnímu vyjádření zkušenosti pobývání v menšinovém jazyce, ale mưžeme rovněž porozumět vymístěnému charakteru menšinového jazyka cestou empirické analýzy, jejíž datový základ Kertészovy texty vytvářejí. To znamená vnímat Kertészovy texty jako součást aktuální sociální reality (jako symptomatický fenomén dneška) a jako takové je interpretovat. Druhý důvod je interpretačně-politický a je veden snahou o zaujetí kritického postoje vůči antisemitským nadinterpretacím a misreprezentacím, které Kertészovo dílo provázejí a které v souvislosti s udělením Nobelovy ceny (možná paradoxně) dokonce zesílily. Jde o nadinterpretace (srovnej Eco 1992) spočívající v tendenčně redukujících a fakty nepodložených výkladech a hodnoceních Kertészových textů, stejně jako Kertésze samotného. Jejich společným jmenovatelem je odmítnutí uznání Kertésze jako mad'arského spisovatele a dále také podsouvání jeho zvenčí připisované židovské identitěl a povaze jednání jako je vlastizrada, plagiátorství, vypočítavý kalkul, povrchnost a neschopnost sebereflexe. ${ }^{2}$ Tyto nadinterpretace zde zmiňuji především z toho důvodu, že právě jejich plíživé prosakování do obecného veřejného diskurzu v Mad'arsku vytváří onen společensko-kulturní kontext, jenž formuje Kertészovu zkušenost jazykového bezdomovectví, se kterou se budeme moci seznámit v druhé části tohoto textu. ${ }^{3}$

\section{Menšinová literatura a menšinový jazyk}

Podívejme se na menšinovou literaturu a menšinový jazyk nejdř́ve obecně, abychom se jí v druhé části textu mohli věnovat na konkrétní rovině na příkladu analýzy Kertészových textů. V souladu s pojetím Deleuze a Guattariho (2001: 29) v tomto textu menšinovou literaturu nechápu jako literaturu psanou v jazyce menšiny, tedy jako literaturu, vytvářenou v původních (etnických) jazycích představiteli sociologicky pojaté menšiny (viz Giddens 1999) uvnitř společnosti, v níž dominuje jiná etnická či národnostní skupina. Menšinová literatura zde nepředstavuje literaturu, kterou tvoří kupříkladu básníci a spisovatelé v České republice romsky, v Rumunsku mad'arsky či v Německu turecky. Menšinová literatura je zde pojata spíše jako literatura, jejíž povaha je určována především její společenskou a mocenskou situací. Je to tedy literatura, kterou menšina, či její představitelé, z formálního hlediska píší ve většinovém/dominantním jazyce, tj. v kanonizovaném jazyce dominantní etnické či národní skupiny, avšak specifickým zpơsobem. Jde např́iklad o literaturu, kterou romský či vietnamský spisovatel, básník nebo filozof tvoří v českém jazyce. ${ }^{4}$

Takto vymezená menšinová literatura vzniká častokrát na pozadí společensko-kulturních situací, v nichž mnoho skupin či komunit nežije v jazyce (nebo ne výlučně v něm), který je 
jim vlastní ve smyslu jazyka původního, jazyka do kterého se reálně či myticky-narativně narodili. Mohou to být situace, v nichž jedinci či skupiny žijí na hranicích více jazyků nebo v jakémsi přechodovém stavu, kdy vlastní (původní) jazyk již neznají a jazyk dominantní většiny si ještě neosvojili. Tato trans-hraniční jazykovost je typická například pro cizince, prristěhovalce, migranty či uprchlíky. Deleuze a Guattari pro takto vymezenou menšinovou literaturu uvádějí př́klady pražské němčiny Ž/židů či americké angličtiny Afro-američanů.

Život a psaní v jazyce, který nám není vlastní, přitom nemusí být zkušeností nutně vyplývající jenom z fyzické dislokace či relokace skupin a jedinců. Menšinovou literaturu může vytvářet kterákoliv subkultura společnosti, která sice geografické hranice dané společnosti nikdy nepřekročila, nicméně kvůli existujícím výrazným sociálním hranicím se posouvá do nedominantní či přímo podřízené pozice, respektive se $\mathrm{v}$ této pozici již předem nachází. Jde o subkultury se zkušeností vymístění (zkušeností symbolické, diskurzivní i sociální marginalizace či přímo umlčování), ačkoli jejich jinakost není v daném společenském kontextu na první pohled úplně patrná. Tito vymístěnci mohou žít i bez neodvratného každodenního vystavování svých „odjinud“ dominantní většině, přičemž právě zvýznamňování těchto symbolických „odjinud“ ze strany většiny je posouvá do vymístěné situace. Tvorba menšinové literatury se tedy v tomto prípadě (jak o tom budou vypovídat Kertészovy texty) zakládá na zakoušení vymístění.

Deleuze a Guattari jdou ještě dále a ptají se na obecnější možnost psát a myslet menšnově. Tj. na možnost, která náleží všem, kteří fyzické či symbolické vymístění nezakouší př́mo, nicméně jsou schopni takovým zkušenostem porozumět (verstehen). Jejich otázka zní již skoro jako manifest: „,...jak vytrhnout svému vlastnímu jazyku menšinovou literaturu, schopnou vyhloubit řeč a uvést ji do pohybu po střídmé revoluční linii? Jak se stát nomádem a pristěhovalcem a cikánem ve svém vlastním jazyce? Kafka říká: krad’te děti z kolébek, tančete na napjatém laně“ (Deleuze a Guattari 2001: 36). Psaní a myšlení v menšinové literatuře je zde vykresleno jako iniciativa, již můžeme formulovat všichni, aniž bychom sdíleli zkušenost fyzické dislokace či relokace, aniž bychom se nacházeli na fyzicky vymezených hranicích různých etnických, jazykových či kulturních světů.

Úsilí být nomádem, prristěhovalcem a cikánem ve svém vlastním jazyce je úsilím myslet z nedominantní perspektivy. Jak vymístěnci, tak jejich rozumějící partneři myslí v řádu menšinové literatury, jež je s to postavit ono umlčované proti utlačujícím a dominujícím významům většinového jazyka. Deleuze a Guattari nabízejí interpretaci menšinové literatury, která ji staví do příznivého světla: poukazují na její potenciální moc vytvářet ostrovy rezistence vůči moci většinového jazyka (srovnej Foucault 1996, 2000). Psaní a myšlení v menšinovém jazyce nemusí být interpretováno jako nevýhoda či handicap, tedy alespoň ne z hlediska obsahu sdělení, které má být formou rezistence předáno. Může naopak představovat užitečné praktiky odporu vůči utlačujícím diskurzivním praktikám většiny. Pozitivní tvořivá síla menšinového jazyka (a potažmo situace displacementu) spočívá ve foucaultovsky pojaté rezistenci, jež na jedné straně zpochybňuje dominanci většinového jazyka, zatímco na straně druhé funguje jako prostředek pro jeho pochopení a analýzu. Vytváŕí-li menšinovou literaturu subkultury či menšiny, může jít o zpochybňování a odmítání vlastní subalterní pozice, pro níž je charakteristická nedostatečnost jakéhokoliv formálního institucionálního př́stupu k politické moci (pro vymezení pojmu „subalterní pozice“ viz Gramsci 1971). Využívají-li se menšinově mož- 
nosti většinového/dominantního jazyka v kritických diskurzech intelektuálů, může jít o podkopávání významů většinové literatury neprrijetím jejího oficiálního postavení a vše-ř́ídícího charakteru. Rezistence je tu pak zaměřená na vše-určující moc většinového jazyka - pevně zakotvenou např́klad ve státních institucích - jako na soubor vědění, jež vymezuje parametry našeho světa (řádu, ve kterém žijeme a máme žít) a to nejtypičtěji tím, že vymezuje, kým jsme a kým máme být (srovnej Foucault 1996; také Bourdieu 1998).

Situace vymezené multi- či bilingválností (viz již zmíněné příklady pražské němčiny Ž/židů či češtiny Romů a Vietnamců) tedy dobře ilustrují v tomto textu užitý význam menšinové literatury. Uchýlení se k pojetí menšinového jazyka jako resistentního prvku však může být jen jedním v řadě príkladů. Tento moment zdůrazňuji jednak kvưli tomu, aby bylo možné zaměřit naši pozornost od literatury směrem $\mathrm{k}$ jazyku vůbec, a jednak také $\mathrm{z}$ toho důvodu, abychom hlouběji porozuměli povaze mad’arsky psaného menšinového jazyka Imre Kertésze v opozici $\mathrm{k}$ mad’arsky artikulovanému jazyku většinovému (o kterém pojednávám v druhé části textu).

$Z$ výše uvedené charakteristiky rezistence a situovanosti v mocenském poli vyplývá, že uvažování není třeba omezit na menšinovou literaturu - můžeme mluvit o menšinovém jazyku jako takovém. $\mathrm{V}$ tomto textu rozlišuji tedy mezi jazykem a literaturou pouze ve smyslu určitého celku řádu bytí a jeho části. Menšinová literatura ve smyslu beletrie, krásné prózy či lyriky (kterou Deleuze a Guattari rozebírají na př́kladu interpretace Kafky) představuje vlastně jakousi podskupinu menšinového jazyka, jenž je vymezen nikoliv substanciálně, ale především prostřednictvím funkce, kterou zastává. Rozhodujícím znakem menšinové literatury a menšinového jazyka obecně je totiž jejich vztahový charakter (srovnej Bourdieu 1998), čili ona relace, která podle Deleuze a Guattariho (2003) existuje mezi tzv. major a minor jazyky. Mluvíme-li o menšinových a většinových jazycích, nemáme na mysli jazyky, které by bylo možné roztřídit do dvou skupin ve smyslu substanciálních entit. Neznamená to tedy vyjadřovat se např́iklad o romštině a turečtině jako o jazycích menšinových, kdežto o češtině a němčině jako o jazycích většinových. Jde spíše o to, že každý (etnicky či národně konstruovaný) jazyk může být menšinovým a většinovým v závislosti na tom, jak je použiván, v jaké konkrétní mocensko-společenské situaci se nachází, jak je s ním v daných podmínkách zacházeno. Menšinový jazyk je jazykem určovaným svým vztahem k jazyku většinovému, či přesněji řečeno, může existovat jenom v tomto vztahu. Jeho funkce spočívá v moci/schopnosti umíst'ovat (vymístovat) elementy většinového jazyka do stavu kontinuálních variací, neboli v potenciálu neustálého nahlodávání homogenizovaného, centralizovaného a standardizovaného řádu většinového jazyka (Deleuze a Guattari 2003: 100-110). Významově a lingvisticky standardizovaný většinový jazyk existuje díky svým konstantám, kdežto menšinový jazyk díky schopnosti tyto konstanty zpochybňovat kontinuálním nabízením jejich významových a lingvistických variant.

Znamená to tedy, že relativizováním konstant většinového jazyka ztrácíme bezpečí a symbolický domov, který nám homogenizovaný a standardizovaný jazyk přes svůj hegemonní charakter, nebo právě díky němu, nabízí? Ztratí své domovy dobrovolní nomádi typu Deleuze a Guattariho, stejně jako ti, kteří nemohou, než mluvit menšinově? Tyto otázky nás vedou zpět k otázkám položeným na začátku tohoto textu - v jakém smyslu žijeme v jazyce a $v$ jakém smyslu jsme $v$ něm doma? Co znamená pobývat ve světě jako jazyce? Lze žít v nějakém jazyce a nebýt $v$ něm doma? 
Za odpověd'mi na tyto otázky navrhuji vydat se cestou, kterou před námi vyznačil již Hans-Georg Gadamer. Podle něj se člověk může v proudu impresí, zkušeností a událostí usadit tak, že si osvojí určitý jazyk. Tímto ukotvujícím jazykem bývá většinou mateřský jazyk jedince. Být doma v takovém jazyce neznamená pouze to, že se pro nás slova a výrazy onoho jazyka stanou familiérními, nýbrž také to, že se nám stane př́ivětivým či domáckým vše, co se těmito slovy a výrazy vyjadřuje či říká. Vrůst či dorůst do určitého jazyka znamená vždy také to, že se nám přiblíží určitý svět s jeho daným významovým řádem a s jeho fakty, které byly z okolního obecného prostředí vyzdviženy jako konstitutivní (Gadamer 1994: 155).

Naučit se kupř́kladu to, že slovo „slon“ označuje velké šedé zvíř́e s velkýma ušima a s dlouhým chobotem, neznamená jen osvojit si základní kategorizační vědění o jeho odlišnosti od lidí, ostatních zvířat a rostlin. Neznamená to také pouze schopnost správně spojit označující s označovaným, tj. přiřadit slovu „slon“ správného savce. Znát slovo „,slon“ také znamená, že jeho prostřednictvím si osvojíme podobu jednoho partikulárního světa, v němž např́íklad nepotkáme slona na křižovatce (tedy alespoň se vší pravděpodobností ne), kde však můžeme očekávat psy nebo holuby. Spatříme ho ale třeba jako živý exponát v zoologické zahradě či jako cirkusovou atrakci. Nám vlastní svět tedy pro nás bude domovem, v jehož významovém řádu slon existuje jako obrovské zvíře exotických dalekých krajin, jako milá pohádková postava našich pohádek z dětství (Jumbo či Babar) či jako drobounká kabala přinášející štěstí. Veškeré tyto slonu připisované významy vytvářejí familiárnost světa, v němž žijeme. Důvěrný charakter takovéhoto partikulárního světa dobře vynikne v kontrastu se světy, v nichž je slon jako konstitutivní prvek vyzdvižen dejme tomu jako objekt lovu či symbol populárního hinduistického boha Ganéšy.

Usazení v důvěrnosti partikulárního světa se přitom samozřejmě neděje jenom prostřednictvím seznámení se se základním slovníkem věcí, předmětů či bytostí, ale také prostřednictvím osvojení si abstraktnějších forem myšlení, konceptů, pojmů a základních struktur uvažování. Svět myšlený a představovaný v jazyku, jenž nezná rody či nemá slovo pro „Já“, bude kvalitativně jiný než ten, který těmito strukturami myšlení disponuje. Naučením se určitému jazyku získáme tedy vědění nejenom o substanční výstavbě našeho světa, nýbrž také vědění o tom, co a kdo do tohoto světa nemá být zahrnuto, respektive co a kdo do tohoto světa nepatří plnohodnotně.

Gadamerova tematizace vztahu mezi jazykem a světem je pro tento text klíčová, nebot' umožňuje artikulovat zkušenost bezdomovectví v jazyce. Jazyk podle Gadamera není jednoduše něčím, s čím člověk ve světě disponuje jako s prostředkem. Jazyk je spíše tím, co nám umožňuje, abychom vůbec nějaký svět měli: abychom v nějakém světě vůbec mohli pobývat. Takové zvýznamňování vztahu mezi jazykem a světem dále ukazuje, že svět zde není míněn ve smyslu obecného a abstraktního prostředí, nýbrž ve smyslu světa sdíleného určitou jazykovou komunitou. Svět je nemyslitelný bez komunikace, jež spojuje ty, kteří mezi sebou mluví. Je to svět vyznačený a utvářený procesy porozumění a snažení se o porozumění (Gadamer 2003: 438-456). Právě z tohoto světa rozumění a porozumění je jazykový bezdomovec vymístěn. Jeho zkušenost a jeho svět-vytvářející-fakty totiž do procesu porozumění a sebeinterpretace dané jazykové komunity nejsou nezahrnuty. Rozvineme-li Gadamerovy myšlenky, můžeme říci, že v př́ípadě pobývání v menšinovém jazyce se usazení v jazyce, díky němuž by se člověku mohl přiblížit určitý svět, nemůže neuskutečnit, je zmařeno, či přestává existovat. 
Vymístěný člověk je postupně vystrkován z přivětivosti své mateřštiny a z hlediska většinového jazykového řádu se z něj stává bezdomovec. Jazyk a svět se pro něj přestávají spojovat v domov: jeho př́běhy o Babarech a Jumbech nebudou vyslyšeny, jeho bohové nepochopeni, jeho existence se stane podezřelou. Jazyk a svět se pro takového člověka rozpojí v důsledku rozpojení jeho mateřštiny na většinový a menšinový jazyk. Kertészovy texty interpretuji v následující části textu jako vyjádření této zkušenosti.

\section{Menšinový jazyk jako vymístěný svěł Imre Kertésze}

V pojetí Deleuze a Guattariho se člověk může stát bilingválním též ve svém vlastním (mateřském) jazyce, a to $\mathrm{v}$ případě, že ve většinovém řádu bude odhalovat a aktualizovat dosud neznámé, nevyjádřené či marginalizované menšinové významy. V tomto smyslu lze také o Kertészovi mluvit jako o bilingválním autorovi. ${ }^{5}$ Jeho vlastním (mateřským) jazykem je mad'arština. Píše v něm však - jak to na mnoha místech zdůrazňuje - jako cizinec. Svět, který začal být mad'arštinou vytvářen přibližně od padesátých let minulého století, pro něj postupně ztratil na př́větivosti: z Kertésze se stal onen jazykový bezdomovec, který už jenom proto, že píše na základě své vlastní zkušenosti, nahlodává a rozvrací většinový řád mad’arského jazyka.

Kertész, abych pro větší plastičnost jenom stručně připomenula kroniku jeho života, byl v roce 1944 jako čtrnáctiletý chlapec deportován do Osvětimi. Z Buchenwaldu, kde byl nakonec osvobozen americkými vojsky, se rozhodl vrátit do Budapešti, do své ,vlasti““. Svou spisovatelskou činnost, jež dlouho zůstávala nepovšimnuta a marginalizována, věnoval v období státního socialismu snaze pochopit a podat zprávu o kulturu-tvořící síle holocaustu. Standardizovaný a hegemonní mad’arský jazyk však jako donucující síla Kertészovu zkušenost být fyzickým i diskurzivním vymístěncem nacismu a komunismu umlčovala, a koneckonců umlčuje dodnes. Kertészova životní zkušenost se do dominantního mad'arského jazyka zkrátka nevešla, přesněji řečeno, nebyla do ní vpuštěna. To, co slova a výrazy dominantního jazyka vyjadřují, Kertésze od světa dominantní mad'arštiny vzdaluje a znemožňuje mu, aby se v něm usadil. V tomto duchu píše ve třetí osobě o sobě samém:

... a [člověk] v tom proudu prázdnoty, jež je u př́ležitosti národních svátků nazývána svobodou, a v nové ústavě - ale vlastně i v té staré, socialistické - demokracií, hloubá nad tím, zda jsou jeho zkušenosti vůbec $\mathrm{k}$ něčemu, nebo zda žil úplně zbytečně.

(Kertész 2001: 12)

Co je tedy ona většinová mad'arština, vưči které se vymezuje Kertészův menšinový jazyk? V čem konkrétně spočívá tento vztah mezi většinovým a menšinovým? Jaké významy reprodukuje a jaké zkušenosti artikuluje Kertész ve svém menšinovém jazyce v opozici k významům a zkušenostem většinového řádu mad'arštiny? S ohledem na Kertészovu životní dráhu lze říci, že takříkajíc krade dítě z kolébky standardizované a homogenizované mad’arštiny zaměřené (či nezaměřené) na hodnocení a interpretaci holocaustu, z kolébky většinového jazyka „tematizujícího“ pamět’ holocaustu a s ní související utváření mad'arských i nemad'arských identit. Jako většinový jazyk se v jeho zamyšleních objevuje onen běžně přijímaný a ,platný jazyk“, který se v mad'arské společnosti postupně vytvořil po druhé světové válce 
a jako dominantní je v podstatě uznáván dodnes. Podle Kertésze je to hegemonní jazyk, který vznikal jako důsledek ritualizace a instrumentalizace vyabstrahované a vyprázdněné paměti holocaustu - paměti Osvětimi. Kertész se k tomuto jazyku staví jako k jazyku těch druhých. Považuje jej za ,jazyk sdíleného světa oné společnosti, jež dál lhostejně funguje“. Jeho vlastní mad’arský jazyk je ten, ve kterém sám píše a kterým byl obklopen v dětství. Jenom $\mathrm{v}$ tomto jazyce, jak sám reflektuje, se mohl stát spisovatelem. Tento mad’arský jazyk je mu ovšem zároveň cizím jazykem, protože v něm Osvětim nemá význam civilizačního traumatu, a tím exkluduje události a zkušenosti, které jsou pro Kertészův svět konstitutivní. Holocaust se v tomto jazyce neobjevuje se vší tíhou neodvratnosti jeho konsekvencí, tj. ani jako trauma celého lidstva, ani jako trauma evropské kultury, a dokonce ani jako trauma mad’arské společnosti. Hegemonní jazyk na holocaust nahlíží jako na trauma několika málo přeživších - těch druhých.

Podle Pétera Nádase (2002) se realita Osvětimi v uplynulých padesáti-šedesáti letech stala univerzálním měřítkem etiky, politického myšlení a právních norem. Z hlediska Kertésze jde však spíše o to, že přes (možnou) existenci takovéhoto univerzálního měřítka v některých kruzích některých evropských společností v aktuálně platném mad’arském jazyce toto měřítko významově zcela jistě chybí. $Z$ menšinové perspektivy jazykového bezdomovce Nádasova slova vyznívají spíše jako normativní přání než jako deskriptivní (sociografická) charakteristika mad'arské společnosti.

Přeživší zakouší většinový jazyk jako cizí, jelikož se v jeho diskurzivním a hegemonním řádu nejsou schopni najít, a to ani přesto, že, lingvisticky vzato, jde o stejný jazyk jako je jejich mateřština. „Překřičí nás básnici, advokáti, filosofové a knězi.“ Hlas těch, kteří jsou nejblíže k události holocaustu, promlouvá, na rozdíl od zmíněných básníků, advokátů, filosofů a knězů tiše, z marginalizované pozice, nedůrazně - menšinově. Alespoň takto charakterizuje tento jazyk Kertész a také celá řada dalších, kteří holocaust přežili. ${ }^{6}$ Podle Kertésze mají přeživší dvě možnosti: bud’ se začlení do významového ráádu „platného jazyka“, anebo si uvědomí svou vlastní izolovanost. Uvědomí si, že mluví a existují v řádu menšinového jazyka. Obě možnosti znamenají uvědomění si toho, že existence v menšinovém jazyce je neodlučitelná od mocenských vztahů; neboli toho, že menšinový jazyk, i přses výzvu kterou nese, je vytvářen za stísněných, omezených a nerovných podmínek.

Vymístění v prrípadě menšinového jazyka, tak jak ho představuje Kertészova zkušenost, je dvousměrným procesem/pohybem. Vymezení lze provést na základě objektu vymístění. $\mathrm{Na}$ jedné straně uvádí standardizovaný řád většinového jazyka díky svému dominujícímu charakteru Kertésze do stísňující pozice jazykového bezdomovce. Na straně druhé spočívá v Kertészově vymístěném menšinovém jazyce potenciál rezistence: tím, že se Kertész stává bezdomovcem ve svém vlastním jazyce, činí většinovou mad’arštinu variabilní. Jinými slovy, díky tomu, že ze své minoritní pozice vymístuje významové a lingvistické konstanty většinového mad’arského jazyka, je schopen dostávat na povrch ono umlčované/menšinové. Jeho menšinový jazyk plní tedy jak expresivní, tak resistenční funkci. Jako expresivní je jeho menšinový jazyk vyjádřením jedné vymístěné zkušenosti, jako resistentní je jeho menšinový jazyk výzvou pro dominantní/utlačující jazykový rád.

Rozbor takto uvedeného Kertészova menšinového jazyka rozvinu dále pomocí identifikace tří specifických, ale pouze analyticky rozlišitelných znaků, jimiž jsou podle Deleuze 
a Guattariho (2001: 29-51) menšinové jazyky charakterizovatelné. Znaky, které činí z určitého jazyka jazyk menšinový, a které lze v Kertészových textech též vystopovat, jsou a) deteritorializace, b) napojení individuálního na politickou sféru a c) kolektivní uspořádání vypovídaní.

\section{Deteritorializace}

Deteritorializaci lze na základě textů Deleuze a Guattariho vymezit jako pohyb, během něhož se rozkližuje onen vztah mezi věcmi a slovy (mezi obsahem a výrazem), jehož existenci v podobě platného a důvěryhodného vztahu vždy v rámci určitého časo-prostorového kontextu předpokládáme. Během deteritorializace se může např́klad destabilizovat námi předpokládaný vztah mezi sociálními institucemi a jejími významy, mezi sociálním jednáním a jeho artikulací. V tomto smyslu je deteritorializace prostředním článkem mezi teritorializací jako stabilním společenským řádem, v němž existuje soulad mezi obsahy a výrazy, a reteritorializací jako restaurováním řádu do nové podoby, jež na sobě nicméně nese stopy deteritorializační změny. Jazyk deteritorializace je $\mathrm{v}$ tomto smyslu jazyk, který je $\mathrm{v}$ dominantním jazykovém řádu schopen rozhýbat existující označující relace a vymanit se tak z dominantním jazykem postulovaných parametrů světa.

Uvádění dominantního jazykového řádu do pohybu vychází v Kertészově př́padě z jeho zkušenosti bytí bezdomovcem ve svém vlastním jazyce. Ze zkušenosti s tím, že svůj rodný (mateřský) jazyk nemůže než používat jako jazyk vypůjčený, že v mad'arštině může psát nanejvýš jako nezvaný a trpěný host, vytvárí pozici vymístěnosti, ze které lze deteritorializační funkci menšinového jazyka realizovat. Velice výstižně shrnuje tuto zkušenost slovy:

Čím cizejší jsem v jazyce, tím věrohodnějším se cítím být a tím věrohodnější je i to, co chci říct. Rád píšu mad’arsky, protože takto lépe procítím, že psaní je nemožné.

(Kertész 2001: 291)

Pro ilustraci deteritorializujícího Kertészova jazyka se můžeme zaměřit na sledování destabilizace identitních pozic, jež dominantní většinový jazyk postuluje. Kertészův jazyk tyto pozice deteritorializuje, tím, že je destabilizuje prostřednictvím reprezentace vlastní zkušenosti holocaustu. Tím poukazuje na to, že jejich hranice nejsou dány přirozeně, nýbrž jsou určovány mocenskými hierarchiemi př́tomnými $\mathrm{v}$ současné mad’arské společnosti. Deteritorializují se zde tedy pevně zakotvené vztahy mezi „námi“ (my) a různými „druhými““ (oni), čili dominantním jazykem vytvářená místa obětí, pachatelů a pouhých přihlížejících.

Kertész je v mad'arském jazyce cizincem, nebot' se v jeho dominantním významovém řádu může objevit jen v pozici „On/Oni“. Má-li každý jazyk nějakou skupinu lidu či národa, nějaké dominantní Já/my, nějaké sdílené Já/my, jež konstruuje sociální svět této skupiny, tak, jak říká Kertész, do této skupiny „my“ on nepatří. Identitní pozice „my“ představuje centrum a Kertész se v dominantním jazykovém řádu nachází $\mathrm{v}$ decentrované pozici. Je vymístěný v rámci významového řádu vlastního mateřského jazyka (displaced within, Bammer 1994). V tomto jazykovém řádu existují jasné hranice a tyto hranice jsou stabilně zakotveny a udržovány také v sociálních institucích nejrůznějšího typu. Existují zde jasně vymezené identitní pozice ve tvaru jakéhosi trojúhelníku vztahů: obětí, pachatelů a přihlížejících. Obětí holocaus- 
tu se stali „Oni/Židé“, to neštěstí se přihodilo ,jim“. Pachatelé holocaustu jsou reprezentováni v obdobné v pozici vyjádřené výrazem „Oni“, tentokrát to však jsou Němci nebo fašisté. Vztah mezi těmito dvěmi pozicemi je v řádu dominantního jazyka jasný: holocaust spáchali Oni/pachatelé jim/obětem, Oni/oběti padli za obět’ jim/pachatelům. Dominantní „my“ (tř̌etí pozice v trojúhelníku) je z celé události vyjmuto do pozice nevinného a nedotčeného přihlížejícího. Identitní pozice „my“ nemá nic společného ani s pachateli, ale ani s obětí. Nejde tedy pouze o to, že dominantní my se zbavuje zodpovědnosti za vinu, ale také o to, že není s to přijmout závazek solidarity, jenž by plynul z identifikace se s obětí.

Kertész rozhýbal takto vymezené identitní pozice $\mathrm{v}$ uvedeném trojúhelníku vztahů. V jeho deteritorializovaném jazyce je holocaust představený jako událost, jež se stala „nám“. Holocaust je řetězcem zcela konkrétních činů, které jsme spáchali „my“ proti „nám“, například „my“ Mad'aři Mad'arům, mad'arští občané mad'arským občanům (nebo dokonce mad'arští křest’ané mad'arským křest’anům, sousedé sousedům, spolužáci spolužákům). Touto reinterpretací přestává existovat jednoznačnost identitních pozic zakládajících se na rozlišujícím aktu bud'-anebo, tedy jednoznačnost kategoriálních hranic mezi „my“ a různými „oni““.

\section{Napojení individuálního na politickou sféru}

Menšinový jazyk je podle Deleuze a Guattariho nemyslitelný bez politického aspektu. Kvůli stísněnému prostoru, ve kterém na zkušenosti se zakládající menšinový jazyk existuje (jde tedy o jazyk, který má primárně expresivní funkci), je v tomto jazyce „,každá osobní záležitost [...] prímo napojena na politiku. Osobní záležitost se stává tím nutnější, nezbytnější, narůstá jako pod mikroskopem, protože uvnitř ní bouří něco zcela jiného“ (Deleuze a Guattari 2001: 30).

Tento aspekt menšinového jazyka Kertész plně reflektuje. Pro jeho pozici je příznačné, že ve svých esejích opakovaně klade důraz na nadindividuální přesah vlastních zkušeností, tedy na to, že jeho zkušenost není jednoduše osobní tragédií jednoho člověka, že přesahuje jeho životní příběh. Holocaust a celá moderně-racionalistická mašinérie, která ho uskutečňovala, je podle něj světovou zkušeností, událostí, která se týká nás všech. Mluví-li tedy Kertész o tom, co se mu jako čtrnáctiletému chlapci přihodilo, mluví současně i o nad-individuálních politických a morálních otázkách naší doby. Ve své osobní zprávě (o takzvaně individuálních záležitostech) popisuje člověka,

kterého zákonné úřady jeho vlastní země - Mad’arska - předaly v rámci tehdejších mezistátních dohod v podobě orazítkovaného zboží cizí velmoci vysloveně pro účely zavraždění, jelikož tato cizí velmoc - nacistické Německo - hromadnou likvidaci Židů provozovala mnohem vyspělejšími metodami.

(Kertész 2001: 92-93)

Tento popis vyjadřuje přesah z roviny individuální zkušenosti a její individuální relevance velice komplexním způsobem. Události, o kterých referuje, přestávají být prostřednictvím zvolené jazykové formy, jež nekompromisně odcizuje spisovatele (sebe samého) od vlastního Já, událostmi ryze osobními. Tím, že ho vměstnává do pozice orazítkovaného zboží, do role neživého předmětu určeného k likvidaci, činí z něj subjekt, jenž se sobě samému stává cizím. 
Jde přitom o jazykovou formu, která je věcným/technickým popisem událostí a zároveň metaforou překračující doslovný význam směrem $\mathrm{k}$ významovým rovinám, které v dominantním jazyku bývají zamlčované. Právě zde, v tomto napětí - v nerozhodnutelnosti toho, zda jde o věcný popis převrátivší se do metaforického vyjádření nebo o metaforické vyjádření převrátivší se do věcného popisu - spočívá neobyčejná síla minoritní výpovědi, vzkazu, který má být společnosti (respektive celému lidstvu) předaný. Výše vyjádřený obsah Kertészovy zprávy, tedy to, že během druhé světové války mohli existovat lidé/spolu-občané, o kterých lze nejenom metaforicky, ale i věcně/doslovně referovat tímto dvojím způsobem, je záležitostí politiky. Minimalisticky vzato se týká všech zúčastněných subjektů (mad’arských úřadů, institucí německého státu a Židů), které se zúčastnily události, během níž se metafora (neboli přesněji řečeno něco, jehož existenci předpokládáme spíše ve figurativním jazyce) přetvořila ve skutečnost. Podle Kertészova menšinového diskurzu se to však nutně týká každé jednotlivé společnosti následující po holocaustu.

Napojení individuálního na politickou sféru se přitom nevyčerpává ve funkci, kterou podobná svědectví plní. Menšinový jazyk se napojuje na politickou sféru také tím, že cílevědomě destabilizuje dominantně platné společenské významy a hodnoty - např́klad prostřednictvím zdůrazňování alternativních/zahalených hodnot. Kertész ukazuje politickou funkci menšinového jazyka např́klad následujícími slovy:

Nevím, jak je možné vyřešit otázku uprchlictví, sociální problémy, jak se ujímat záležitostí chudých zemí a hodnotných lidí, nevím, jak lze vytvořit nový bezpečnostní systém. Jedno ale rozhodně vím: civilizace, která jasně nevysloví vlastní hodnoty nebo která vyslovené hodnoty zanechá svému osudu, vstupuje na cestu zkázy a postupného zániku.

(Kertész 2001: 42-43)

Napojení menšinového jazyka na politickou sféru tedy neznamená prosazování velkolepých politických programů. Nejde tu ani o snahu dosáhnout dominantních mocenských pozic, umožňujících takovéto programy realizovat. Politika menšinového jazyka vycházející z individuální zkušenosti, z individuální životní dráhy spisovatele, zde spíše spočívá v artikulaci a ochraně hodnot, které jsou v rámci jakéhosi sebeklamu dominantními významovými rády umlčovány. Jde o dynamický, nekončící proces uvádění do pohybu zdánlivě stabilních pozic. Obecně platný diskurz mad’arského jazyka je vzhledem k jazyku jeho vnitro-společenských cizinců/vymístěnců (jako je např́klad Kertész) jazykem většinovým. Nemůže však uniknout tomu, aby s ním bylo nakládáno jinak. Nemůže uniknout tomu, aby byl těmito cizinci/ vymístěnci považovaný za minoritní vzhledem k nad-národním kulturním hodnotám a významům, které jsou v jazyce vymístěných reprezentované (srovnej Deleuze a Guattari 2003: 103).

Politická funkce menšinového jazyka tedy spočívá v deteritorializaci dominantních většinových významů, ve zpochybňování údajně daných mocenských pozic a práv. Současně se však v menšinovém jazyce vzhledem $\mathrm{k}$ této politické funkci odehrává i proces reteritorializace. Podle Deleuze a Guattariho může minoritní jazyk fungovat/působit pouze za předpokladu, že bude poskytovat určité stabilní významové konstanty činicí menšinový jazyk lokálně-většinovým jazykem. (V př́ípadě Kertészova jazyka je samozřejmě otázkou, v jaké dimenzi - symbolické, geografické - máme tuto lokalitu, toto teritorium, hledat.) Jedině za předpo- 
kladu konstantních jazykových významů, tj. za předpokladu důsledné stability/invariability, lze totiž z minoritních pozic vynutit (alespoň nějaké) politické uznání. Jinak řečeno, jedině za předpokladu konstantních minoritních významů lze smysluplně plnit resistentní funkci menšinového jazyka.

Kertész deteritorializuje většinové významy a snaží se o reteritorializaci významu v řádu menšinového jazyka. To, co stojí v opozici v dualitě deteritorializace a reteritorializace je na jedné straně lhostejná kultura mad’arské společnosti, jež se zmůže maximálně na uskutečňování kultury holocaust-konformismu, holocaust-sentimentalismu, tedy kultury se svým vlastním kánonem, systémem tabu a nabízenými holocaust-produkty určenými pro konzum. Na druhé straně pak stojí kultura prijímající traumatickou zkušenost holocaustu za vlastní, tedy kultura, v níž se holocaust stává sdílenou zkušeností mad’arské společnosti a nikoliv jenom př́mou a vzpomínkovou zkušeností židovské komunity. Neboli, je to/má to být kultura, jež si plně uvědomuje, že za cenu nevypočitatelných ztrát získala nevypočitatelně hodnotné vědění (Kertész 2001: 90).

Toto získané vědění nás z roviny politiky vede zpátky do osobní roviny. Ukazuje nám, že vztah mezi individuálním a politickým je třeba si představit v podobě uzavírajícího se kruhu. Politicky relevantní vzkaz se v menšinovém jazyce formuje na základě nějaké negativní individuální zkušenosti, vychází tedy z osobní zkušenosti, aby se do ní nakonec také vrátil. Individuální se napojuje na politickou sféru, dostává se do veřejné komunikace a objevuje se tam jako zkušenost, jež reprezentuje celospolečenské hodnoty. Porozumění těmto hodnotám má následně vést zpět k individuálnímu, $\mathrm{k}$ reflexi vlastního jednání a voleb jedince. Morálním úkolem současnosti je podle Kertésze rozpoznat, že je třeba

přetvořit negativní zkušenosti na pozitivní činy a porozumět nutnosti vybudování solidarity, jež sahá ke kořenům našich soukromých životů.

(Kertész 2001: 109)

V tomto tedy spočívá od etiky neoddělitelná politika Kertészova menšinového jazyka: $\mathrm{z}$ vědomě prijaté vymístěné pozice apelovat na zodpovědnost lidí a snažit se přitom o vytěsnění relativizujících otázek, jež se snaží vypátrat, jestli má v dnešním světě takové snažení vůbec ještě nějaký smysl.

\section{Kolektivní uspořádání výpovědi}

Popis menšinového jazyka na základě třetího znaku vymezeného Deleuzeem a Guattarim vyžaduje pouze malou změnu úhlu pohledu, a to vylíčení nadindividuálního přesahu menšinového jazyka z hlediska (minoritních) významů, které jsou artikulovány ve jméně určité skupiny lidí. Řekli jsme, že osobní výpověd’ v řádu menšinového jazyka získává vždy politický význam, ted' $\mathrm{k}$ tomu můžeme přidat, že nabývá také kolektivního významu, že se uspořádává v kolektivní dimenzi.

To, že menšinový jazyk mluví vždy za nějakou skupinu lidí či ve jménu této skupiny , vyplývá z podmínek stísněného prostoru, ze kterého menšinový spisovatel promlouvá. Kvůli tomuto stísněnému a mocensky ovládnutému prostoru neoplývá menšinový diskurz talenty - nikdy nebude mít nadbytek těch, kteří jsou schopní promluvit. Pro společenství lidí, kteří se vrátili z vyhlazovacích táborů, je to obzvlášt' bytostná charakteristika: $v$ jejich prrípadě je 
vznik diskurzivního „blahobytu“, jenž by umožňoval ryze osobní výpovědi (ono moderní soustředění se výlučně na vlastní ego), naprosto vyloučený jak v kvantitativním, tak v kvalitativním smyslu slova. Kvůli neblahým podmínkám stísněného prostoru tedy menšinový spisovatel nemůže než psát v souladu s kolektivní funkcí vypovídání. Zároveň však platí, že právě díky tomuto stísněnému prostoru je vůbec schopen resistentní výpovědi a dokáže psát, vytváŕeje solidaritu s nějakou skupinou lidí. „Žije-li spisovatel na okraji nebo stranou svého křehkého společenství, je díky své situaci tím spíš způsobilý vyjadřovat jiné, potenciální společenství, kout nástroje jiného vědomí a jiné vnímavosti“ (Deleuze a Guattari 2001: 32).

Ve jménu jakého potenciálního společenství mluví Kertész? Jakému společenství věnuje svou jinou vnímavost? Kolektivní dimenzi jeho výpovědí jasně ukazuje jeho tvrzení, že doopravdy se může domluvit jenom s dalšími Židy. Podobně jako ostatní Židé se i on cítí, jakoby stál mimo celé lidstvo (Kertész 2001: 5-6). Je to vlastně izolovanost od hlavních proudů společnosti, od významů platných národních jazyků, jež vytváŕí porozumění a solidaritu mezi lidmi, kteří se cítí být existenciálně i diskurzivně vymístěnými. Je to kolektivita lidí, kteří myslí a žijí v jazycích, jež jim nejsou určeny: jsou to jazyky, které si od dominantní většiny jenom vypůjčili, přičemž doufají, že tato je $\mathrm{v}$ těchto jazycích ještě nějakou dobu strpí (Kertész 2001: 288). Kolektivní dimenze osobního vypovídání tedy zahrnuje všechny, kteří žijí v tomto hierarchicky uspořádaném vztahu ,vypůjčenosti“, neboli ty, jejichž jazyky jsou periferním „jazykem hostů“ (Kertész 2001: 291).

Nelze si zde nevšimnout, že také zde, v artikulaci kolektivní dimenze menšinového vypovídání, se odehrává určitá deteritorializace většinových významů. Destabilizuje se především ten jednoznačný vztah, který se ve většinovém diskurzu předpokládá mezi sociální kategorií židovstva a skupinou lidí, jež prý do této kategorie patř́i. Deleuze a Guattari tvrdí, že kolektivně uspořádaná menšinová literatura je záležitostí národa. Z Kertészových textů je však zřejmé, že slovo národ je zde spíše metaforou. Je to „národ“ ve smyslu morálního společenství:

...židovství si původně získalo pověst morální kultury: dalo lidstvu víru v jednoho Boha. Být Židem - dnes je to podle mě opět především etický úkol. Pro mě je to věrnost, zachování a memento: mené, tekel, ú-parsín na zdi každého totalitního útlaku.

(Kertész 2001: 69)

To, co tedy utváríí ono potenciální společenství lidí, je zakoušení vymístění a porozumění tomuto vymístění, sdílená pozice cizince a vědomá věrnost hodnotám, které z této pozice vyplývají. Kolektivní uspořádání výpovědi v Kertészově menšinovém jazyce tedy v žádném př́ípadě neznamená přidružení se $\mathrm{k}$ tribalistickému myšlení: být Židem není otázkou přináležitosti k etnicky vymezené skupině. Je spíše destabilizací binárních identitních struktur mezi důvěrnými my a cizími oni, $\mathrm{v}$ míře, $\mathrm{v}$ níž se židovská identita reinterpretuje $\mathrm{z}$ hlediska morálních stanovisek. Utváří se tedy kolektivita, která se nevymezuje podél zdánlivě jednoznačných a neměnitelných etnických hranic mezi Židy a nežidy. Ostatně už jenom stanovení těchto hranic je etickou otázkou a jako takové, ignorující etnické, národní, geografické a náboženské rozdíly, může podle Kertésze rozlišovat pouze mezi těmi, kteř́ jsou $\mathrm{s}$ to hledět $\mathrm{v}$ tváŕ evropskému dědictví genocidy a těmi, kteří toho schopni nejsou. 


\section{Místo závěru}

Přes deteritorializující funkci menšinového jazyka, tedy přesto, že z menšinové jazykové pozice lze formulovat rezistenci vưči dominantním jazykovým významům a zprostředkovaně také vůči institucím fungujícím na základě těchto významů, zůstává Kertész vymístěným. Možnosti artikulace rezistence nepřináší Kertészovi ulehčení v jeho zkušenosti jazykového bezdomovce. Zdá se tedy, že v menšinovém jazyce artikulujícím zkušenost vymístění vždy zůstává jakýsi nedostatek. Jako kdyby uspokojená usazenost v důvěrnosti partikulárního světa nebyla slučitelná s destabilizujícím charakterem menšinového jazyka.

Znamená to pak, že bytí doma $\mathrm{v}$ jazyce je $\mathrm{v}$ tomto případě objektem nekončící a nenaplnitelné touhy? Existuje možnost zajištění domova v menšinovém jazyce přesto, že je tento jazyk ze své podstaty reaktivní? Je tedy Kertészův menšinový jazyk př́íkladem vymístění jako dialektiky odchodu a zůstávání? Vede umožňování a znemožňování pobytu v jazyce vymístěnce nevyhnutelně, ale bezpečným krokem směrem k pobývání ve více světech zároveň?

\section{Poznámky}

Děkuji Csabovi Szaló a Petrovi Kouřilovi, že byli mými prvními kritickými a rozumějícími čtenáři.

1 Tedy identitě, která není totožná s osobní identitou (self-identity) vznikající prostřednictvím sebereflexe, osobní identitu jedince dokonce ignorující.

2 Pro shrnutí nejtypičtějších z těchto názorů a pro stručný přehled médií reprodukujících tento veřejný diskurz viz např́íklad Vásárhelyi 2002.

3 Zmiňované antisemitské nadinterpretace sdílejí mnoho společného s většinovým jazykem, v jehož opozici se Kertészův menšinový jazyk formuje. Vrátím se k tomu v druhé části textu.

4 Pro úplnost krátké zpřesnění. Konsekventně vzato, samozřejmě nejde o to, že by sociologicky chápaná menšina, žijící uprostřed společnosti dominované jinou etnickou skupinou, nemohla ve svém vlastním jazyce psát menšinovou literaturu ve zde používaném významu. Netvrdím tedy, že např̀. turecká literatura psaná v Německu nemůže být za žádné okolnosti psaná jako menšinová. Rozlišováním mezi dvěma významy používání menšinového jazyka chci upozornit na to, že samotné používání jazyka nějaké menšiny není dostačujícím kritériem proto, abychom o něm mohli mluvit jako o menšinovém ve smyslu Deleuze a Guattariho. I v jazyce etnické menšiny lze totiž psát a myslet reprodukujíce významový rád většinového jazyka. V před-převratové střední Evropě jsou toho dobrým př́íkladem, jak mě na to upozornil Csaba Szaló, socialistické romány psané v jazycích národnostních menšin. O dostačujících kritériích menšinového jazyka v jeho zde užitém smyslu pojednávají následující odstavce mého textu.

5 V tomto ohledu ponechávám tedy stranou Kertészovu bilingvalitu jako překladatele např́klad Friedricha Nietzscheho a Ludwiga Wittgensteina do mad'arštiny.

6 Marginální charakter a proces marginalizace hlasu přeživších jsou dobře ilustrovány diskusemi o způsobu, jakým diskurzivní řád historické reprezentace holocaustu překřičí diskurzivní rád svědectví. I toto patři pod zkušenost vyhoštěnosti z/do jazyka.

7 Kertész zde odkazuje na Da 5, 25-30. V tomto biblickém příběhu o třech záhadných slovech se zvěstuje zánik království Belšasara. Význam uvedených slov vyložil prorok Daniel následovně: Bůh sečetl (mené) Belšasarovo království, zvážil (tekel) ho a protože shledal Belšasara lehkým, rozdělil (ú-parsín) jeho ř́íši mezi Médy a Peršany. 


\section{Literatura}

Bammer, A. 1994. Displacements: Cultural Identities in Question. Bloomingtion: Indiana University Press.

Bourdieu, P. 1998. Teorie jednání. Praha: Karolinum.

Deleuze, G., Guattari, F. 2001. Kafka. Za menšinovou literaturu. Praha: Herrmann a synové.

Deleuze, G., Guattari, F. 2003. A Thousand Plateaus. Capitalism and Schizophrenia. London: Continuum.

Eco, U. 1992. Interpretation and Overinterpretation. Cambridge: Cambridge University Press.

Foucault, M. 1996. „Subjekt a moc“. In M. Foucault Myšlení vnějšku. Praha: Herrmann a synové.

Foucault, M. 2000. „The Ethics of the Concern of the Self as a Practice of Freedom“. In P. Rabinow (ed.) Michel Foucault -Ethics, Subjectivity and Truth. London: Penguin.

Gadamer, H. G. 1994. „Miként járul hozzá a költészet az igazság kereséséhez“ (Jak přispívá poezie k hledání pravdy). In H. G. Gadamer $A$ szép aktualitása (Aktualita krásy). Budapest: T-Twins.

Gadamer, H. G. 2003. Truth and Method. New York: Continuum.

Giddens, A. 1999. Sociologie. Praha: Argo.

Gramsci, A. 1971. Selections from the Prison Notebooks. London: Lawrence and Wishart.

György, P. 2003. „A hajléktalan“ (Bezdomovec). Élet és irodalom. XLVII, 42.

Kertész, I. 2001. A számüzött nyelv (Vypovězený jazyk). Budapest: Magvető.

Kertész, I. 1975. Sorstalanság (Bezosudovost). Budapest: Magvető.

Nádas, P. 2002. „Kertész munkája és a témája“ (Kertészovo dílo a téma). Élet és irodalom. XLVI, 42.

Vári, Gy. 2002. „A Sorstalanság történelemszemléletéröl“ (O pojetí historie v románě Bezosudovost). Élet és irodalom. XLVI, 42.

Vásárhelyi M. 2002. „Nobel-díj - történelmi keretben“ (Nobelova cena v historickém kontextu). Élet és irodalom. XLVI, 42.

\section{Autorka}

Eleonóra Hamar působí na Ústavu religionistiky FF MU v Brně. Zajímá se o teorie narativního konstruování světa, o kulturní dějiny moderního židovství a v poslední době rovněž o teoretickou religionistiku. Kontaktní e-mail: hamar@phil.muni.cz 